\title{
Offering Dance in the Performance of Topèng Dhâlâng Madura as a Creative Industry Commodity
}

\author{
Eko W. Rahayu ${ }^{1, *}$ Warih Handayaningrum ${ }^{1}$ Jajuk D. Sasanadjati ${ }^{2}$ Arief Sudrajat ${ }^{3}$ \\ ${ }^{1,2,3}$ Universitas Negeri Surabaya, Indonesia \\ *Corresponding author.Email: ekowahyuni@unesa.ac.id
}

\begin{abstract}
This study aims to examine the criteria of offering dance forms in topèng dhâlâng performance as an industrial commodity. The topèng dhâlâng is a traditional dance performing art with the genre of dance drama in the Sumenep Regency of Madura, East Java. A characteristic of topèng dhâlâng is as the offering dance whose existence is very important and is never abandoned. In contextually, people place the existence of offering dance in the topèng dhâlâng performance due to some reasons. The offering dance has complex functions and meanings for event organizer who holds the topèng dhâlâng performance, audiences, as well as artists. Given the importance of the existence of offering dance in the topèng dhâlâng performance, it becomes an object of economic commodity. According to the perspective of the arts industry/ creative industry, the existence of offering dance is an industrial commodity that needs to consider the performance packaging forms. The aesthetic offering dance form packaging is one of the important strategies to create bargaining value as well as improve sales performance for topèng dhâlâng performance products. The offering dance form packaging, which has the great value and is in demand by the society, has the aesthetic criteria both visually and audio.
\end{abstract}

Keywords: Offering dance, Topèng dhâlâng, Industrial commodity.

\section{INTRODUCTION}

Topèng dhâlâng Madura includes forms and styles of performing art in the traditional Madurese drama dance genre that exists and is popular in the Sumenep Regency, Madura, East Java. People called the dance as topèng dhâlâng because there is a dalang (puppeteer) who tends to dominate the performance such as in the wayang kulit performance. Dalang roles include storytelling, dubbing all dialogues of the characters, regulating and controlling from beginning to end of the show. In addition, all dancers in the topèng dhâlâng performance are males and they always wear their mask according to the characters played.

Topèng dhâlâng performance in the society have various functions, yet the most primary is as a ritual medium. Topèng dhâlâng performances in the Sumenep Regency are usually held at all night long from 8 PM to 4 AM. The Topèng dhâlâng performance at the ritual events traditionally hold selected casts and main casts originating from the Mahabharata or Ramayana stories in various themes. The performance consists of three parts in structurally, including: (1) opening performance contains the opening/ welcoming music which is presenting Madurese folk music that followed by greetings prologue by a puppeteer, then performing an offering dance; (2) The topèng dhâlâng dance drama performance with the selected casts (Mahabharata or Ramayana); and (3) closing performance that is the core ritual performance by holding a main cast namely Bathara Kala (Murwakala).

At every topèng dhâlâng performance, there is always an offering dance that is performed at the beginning of the show. The offering dance performance at the topèng dhâlâng Madura performance textually serves as an opening performance aiming to notice audiences that the topèng dhâlâng performance will be soon begun. The offering dance performed can be in the forms of a solo dance, a paired dance, or a group dance whether it is a male or a female dance style. The offering dance is one of the characteristics in the topèng dhâlâng genre that cannot be vanished. The offering dance performance has various functions and meanings which are associated with the purpose of holding a celebration or an event by the community. 
For the community as well as the event organizer, an offering dance performance can be meaningful as either an offering or a welcoming expression in the form of expressing an appreciation and gratitude to the invited guests for attending the reception or ritual celebration (rokat). It is also as a request expression of blessing, safety, smoothness, and prosperity for the implementation of the celebration. The choice of the offering dance form and theme presented to the audience is according to the prestige following both artists and an event organizer. The event will be remembered and appreciated by audiences if the offering dance presented can attract, fascinate, impress, and entertain them well. Thus, the event/ celebration organizer will bring a prestige impact because they are able to present an impressive selection of dance forms then it will be a memorable event for many people.

Therefore, the event organizers who present the topèng dhâlâng performance always consider the choice of the offering dance form and style. When they give a call to the topèng dhâlâng group for the performance, not only booking the day and date of the celebration (in local term, it is called ngolong tangghal), but they also prepare a choice of the theme for casts in the topèng dhâlâng performance afterwards. Besides, the choice of the offering dance form and style should be considered and determined.

On the other hand, according to the topèng dhâlâng artists, an offering dance presented has a very important function as a strategy to attract the interest and attention of audiences as well as a promotional medium for the artists. In the perspective of arts and creative industry, the packaging of the offering dance which has been presented is an important thing to be considered because it is a form of economic commodity that includes a bargaining value or sales performance for its performance product. Therefore, each topèng dhâlâng group in the Sumenep area also strives to be able to pack an aesthetic offering dance form both audio and visual by adjusting the society's tastes (stake holder). One of strategies used is preparing various choices of offering dance form and style that include an aesthetic value and are interested to the society.

\section{METHODS}

Qualitative method was used in this study in order to obtain data descriptively on the phenomena studied [1]. The research data was obtained through a field study includes direct observation of several events of topèng dhâlâng Madura performance which was held in the Sumenep Regency in 2017-2019. In addition, unstructured interviews were conducted in-depth by researchers with several relevant informants including event organizers and artists who involve in the Madura performance of topèng dhâlâng. It was in order to obtain information about their perspectives towards the topèng dhâlâng performances. Data analysis was carried out by three stages include data reduction, data presentation, and conclusion [2, pp. 19].

\section{RESULTS AND DISCUSSION}

\subsection{Topèng Dhâlâng Performance in the Life of the Madurese Community}

Several literature indicated that the existence of topèng dhâlâng performing art in Madura has been going on for centuries. According to Timoer [3, pp. 28], the topèng dhâlâng performance has approximately existed and is still sustainable since the 13th century. The topèng dhâlâng performance is included in the masked dance drama genre and can be categorized as a complex performing art (Total Theatre) in which various art elements support the unified form of performance, such as: fine arts, music arts, dance arts, theater arts, and literary arts [4, pp. 3]. These various elements of the performance are all visualized in the form of a very distinctive and unique performance with Madurese culture. In addition to the characteristic of topèng dhâlâng Madura performance holds a show based on the story of Ramayana and Mahabarata which are valuable in guiding, it also contains some entertaining show values.

Even though the existence of the topèng dhâlâng Madura performance had experienced fluctuation, in which has a negative impact on the life of traditional performances in the globalization era, the topèng dhâlâng Madura performance in Sumenep Regency is still exist and can be enjoyed by public or community until these days. The topèng dhâlâng keeps existing in the Sumenep area due to functional factors for its performance. The topèng dhâlâng has become an integral part of social life of the Madurese community. In addition, supporting artists continued improving preservation efforts through renewal actions to meet the taste of the supporting community based on the recent era. These renewal actions were conducted through form development and performance structure. Other efforts were also carried out such as regenerating dancers and musicians (najâghâ), decorating artistic arrangements also arranging the stage by utilizing digital technology, developing stories or casts, and developing gendhing-gendhing as a support in forming the topèng dhâlâng performance [5].

Residents in the Sumenep area are Madurese who are known to always uphold the values and norms of their social life. Most of Madurese are Moslem and they are carrying out Islamic law who always adhere to the phrase of "abhantal syahadat, asapo' iman, apajung Allah", which means the profession of faith is used as a pillow, the faith as a blanket, and Allah is as community's umbrella. Adherence to Islamic principles among Moslem Madurese is indicated to the Madurese 
dress code which follows to the Islamic law such as women wear sampèr (long dress), kebaya, and burgo' (veil or hijab); meanwhile, men wear songko' (as a head cover) and sarong (to cover intimate parts or aurat). However, the Madurese maintain various ancestor traditions that are holding traditional rites called rokat. Rokat is a ritual to eliminate or get rid of bad luck as an individual or group facing [5]. There are various types and forms of rokat performed by Madurese community such as rokat bhuju', rokat ojan, rokat tasè' or rokat pangkalan, rokat dhisa, rokat sombhêr, rokat bèngko, and rokat pandhâbâ. In addition, these rokats performed at the birth time, adulthood phase (initiation, circumcision), asking for forgiveness (meruwat ritual), Qurban event, marriage, spiritual guidance, and funeral [6, pp. 20].

Rokat pandhâbâ relates to the personal interest that is still held as a big event. It is a purification ritual for sukêrta people (dirty people) carried out to keep orèng pandhâbâ away from various magical dangers. The rokat pandhâbâ was carried out due to a myth about the existence of orèng pandhâbâ. The pandhâbâ people were believed to be suffering from evil upon their birth including children who were in the category of sukêrta or those who were threatened by various magical dangers. The orèng pandhâbâ is a term for people who are identical with the Pandawa. They are Pandu's five sons who are in the Mahabarata story namely Puntadewa, Werkudara, Arjuna, Nakula, and Sadewa. The story of Pandhawa life journey always plagued with misfortunate, fortunately, they were able to overcome the problems and win against Bharatayuda. The rokat pandhâbâ procession consists of several ritual stages, including performing arts as the main medium in the implementation of rokat pandhâbâ. The topèng dhâlâng performance serves as an entertainment to enliven various social events such as weddings, circumcisions, thanksgiving, and etc.

Topèng dhâlâng performance is a performing art which is traditionally presented in the rokat pandhâbâ event by holding the story of Bathara Kala which tells about the origin of Bathara Kala birth. In the context of rokat pandhâbâ, the topèng dhâlâng performance aims to be a ritual medium as the main requirement which means to ward off bad luck. The topèng dhâlâng performance in the rokat pandhâbâ event hold the Bathara Kala story as an explanation, validation, complement or reinforcement of the event, and as a medium of integration for the community [7, pp. 75]

\subsection{The Offering Dance Commodification in the Topèng Dhâlâng Madura Performance}

Commodification is the process of packaging an object to be more profitable for many parties. It means the process of transforming goods and services, all of which are valued due to their use value, into valuable commodities since they can bring profits in the market after being packaged [8, pp. 17]. In the practice of commodification, there is a packaging process so that the object becomes attractive to the public (consumers). The packaging process for the offering dance in the topèng dhâlâng performance certainly involves an aesthetic element of art. The aesthetic function of commodities is to accelerate commodity exchange rates and changes in value [9, pp. 34]. This exchange rate is the value offered to the consumers. In commodification, use value will change to exchange value. This happens after the practice of commodification in the form of packaging has been adapted to the context of the consumer or the supporting community.

The factors that influenced the commodification of offering dance as a commodity are the increasing culture of consumerism in the Madurese community life. The emergence of a consumerist culture is due to the wide variety of choices presented, offering alternative values and subtly entangling us in a network of consumer interpretations and involvement with all values, including our own [10, pp. 23). In this regard, gripped our lives that was consumed was an idea, and the consumption has spread to all cultures. We have also witnessed the commodification of culture. Furthermore, in modern society, the consumption is not only from goods but also from human services as well as human relations [11]. In this case, the emphasis is on cultural objects, with various elements, one of which is art, including offering dance in topèng dhâlâng performances in the Sumenep, Madura.

The commodification of topèng dhâlâng performances as a product of traditional performing arts or local genius products of the Madurese community is now experiencing competition. In line with Barker's statement, commodification is a process associated with object capitalism; signs are transformed into commodities, which are under the primary purpose of being sold in the market [12, pp. 517]. The Barker's statement clearly shows that commodification is carried out with the aim that the object (in this case, the performing art of topèng dhâlâng) can be sold in the market. This statement means being accepted by the community and having a broad audience. One of the commodification processes in the topèng dhâlâng performance is by formulating the packaging of offering dance as a commodity object. The commodification of the topèng dhâlâng performance is carried out through a packaging approach to the form of offering dance. With this modification, it is hoped that it will bring a positive impact that is to increase the economic income of the supporting artists and preserve the performing arts of topèng dhâlâng itself.

\subsection{The Form of Offering Dance in the Topèng Dhâlâng Performance}


In addition to the previous explanation, there is always an offering dance in every topèng dhâlâng performance as its characteristic. The existence of offering dance in a topèng dhâlâng performance is like two sides of a coin that function to complement each other. The offering dance performed at the beginning of the show served as the opening act. It means as a sign that the topèng dhâlâng dance drama will soon begin. On the other hand, the aesthetic packaging of the offering dance form can attract the audience's attention. Contextually, the performance of the offering dance also has an important position and meaning for the supporting community, both for the supporting artists, the audience, and the organizers of the celebration who present the topèng dhâlâng performance. Therefore, the packaging of the performance form of the offering dance is also a significant thing to consider.

The term 'offering dance' means construction of a dance form with the offering theme, or a dance form whose appearance functions as an offering expression to the audience or guests. The meaning of this form is related to the textual construction of art works such as the offering dance that has concrete actual forms (can be seen and heard) and reality that appears abstractly in something that is told or read in a book which can only be imagined [13, pp. 17]. Dance aims to communicate the ideas of its creator to the audience. In expressing these ideas, dance is not only about a series of movements but also has a form, whole system, and unity of characteristics or modes. The dance form is something that appears as a series of contents from its elements [14, pp. 34). As a complete form of composition, dance consists of various components, and the relationship between the elements must be coherent. This is intended not to reduce or add new features without destroying the unity that has been achieved. A form is an external form resulting from the arrangement and execution of the observed motor elements. The external form is concerned with processing the basic material and determining the interplay between the components used [15, pp. 30-31]. Soedarsono [16, pp. 40-41] stated that the basic elements of dance include motion as basic material, floor design, top design, music design, dramatic design, dynamics, group choreography, themes, make-up and costumes, dance properties, lighting, and programming.

Each dance form certainly has its uniqueness or strength of values that become the main attraction of the performance. The interest lies in the element of beauty or aesthetics contained in the form of the performance. Aesthetics is the paramount quality that gives pleasure to the senses or memories of the audience who enjoy it [17, pp. 36]. According to Bouvier [18, pp. 411-414), the performing arts of the Madurese community are performances that provide a feeling of pleasure called lebur, which means entertaining and fun. The form of the offering dance in the topèng dhâlâng performance is deliberately prepared by performing artists with lebur criteria, which has the criteria of uniqueness, and an aesthetic form, which can be observed from several supporting elements. Based on the results of direct observations of several topèng dhâlâng performances (over several years from 2012 to 2019) and observations of several video recordings of performance dances, several criteria can be identified regarding the elements of the offering dance. The criteria for offering dance forms can be categorized into two supporting elements, namely visual elements and audio elements.

Visual elements are various elements that make up a dance that can be captured by the sense of sight. The dance form that has an attraction for the audience is the female group dance form, which is a dance form that expresses the life behavior of a group of women. Physically, a woman's body has the potential to have flexibility in the construction of dance forms so that it can produce an artistic and exotic visual touch. Female dance forms that are displayed through women's stylistic techniques have more appeal for their flexibility. Visually, the characteristics of the elements that make up the dance include dance moves, dance styles, design of dance make-up and clothing, and dance properties. Firstly, dance movement is the basic material of a dance form. The elements of the female dance movement are dynamic, both lyrical and rhythmic, in the form of pure and meaningful movements, and of course, in Madurese style. Secondly, the dance style is the identity of the dance or the performance characteristic related to the performance technique, especially that performed by the female dancers. Thirdly, make-up and dance clothing designs are visual elements that are easily captured by the audience, especially dance clothing designs that are contemporary. One of its characteristics is that it looks glamorous but still shows ethnic elements or accentuates local elements, such as clothing made from batik cloth as a product of the Madurese community pride. Besides, the dance property refers to the supporting element of the dance form, which is also a consideration related to the theme of the offering dance and also supports the impression of the dance style. In addition to the shawl (pènjhung), the property also utilizes traditional ritual equipment such as bowls, flowers, yellow rice. As described above, one dance form that is now popular is the Moang Sangkal dance, a form of offering dance that depicts a group of Madurese girls performing a ritual of ward off misfortune.

Audio elements are dance-forming elements related to dance music elements. In this case, the dance music is based on traditional or classical gamelan music with garap gendhing technique with Madurese style, and there is a Madurese kèjhungan performance in it. The characteristics of Madurese kèjhungan are ong-klaongan (shouting) and lè-kalèllèan (singing). Kèjhung ongklaongan is a kèjhungan (singing) that describes a loud 
voice but is not merely a shout but is concerned with optimizing voice height, tension, and loudness. Kèjhung lè-kalèllèan is a song that describes the expression of feelings of grievance. The meaning is more connotative and presents an emotional impression, outpouring of the heart, and sadness, especially kèjhungan binè' (princess) is considered the most likely to present an atmosphere of sad emotion (an atmosphere of lamentation and sorrow).

\section{CONCLUSION}

The topèng dhâlâng performance is one of traditional arts that is the most familiar to the life of the Sumenep society. The existence of topèng dhâlâng performance, as a product of traditional performing arts, can survive in the midst of fierce competition with various modern performing arts which are easily loved by the millennial generation. Moreover, there is a form of offering dance in the show that has a function and complex meanings. The aesthetic value of the offering dance form performance, includes charming, impressing, and entertaining (called "lebur" in the local language), is what determines the selection criteria. The form of offering dance that has a "lebur" characteristic is a dance form appearance that is able to provide an exhilarating experience and inspiration. The offering dance performance is the result of the artistic creativity of the Madurese community whose existence includes taste expressions and supporting community experiences. The taste has a broad meaning including the value of traditional life, ethical, aesthetic sense, and cultural. Based on the industry perspective, an offering dance in the topèng dhâlâng performance can become an industry commodity that has a promising marketability or a bargaining value also can support the economic improvement of the artists. The offering dance form in the topèng dhâlâng performance is a cultural product that reflects the cultural values of society who own it.

\section{REFERENCES}

[1] A. Salim, Teori dan Paradigma Penelitian. 2nd ed. Yogyakarta : PT Tiara Wacana., 2006

[2] M.B. Miles and A.M. Huberman, Analisis Data Kualitatif: Buku Sumber Tentang Metode-Metode Baru. Jakarta: UI Press, 1992.

[3] S. Timoer, Dramatari Topèng Dhâlâng di Jawa Timur. Jakarta: Proyek Sasana Budaya Direktorat Jenderal Kebudayaan Departemen Pendidikan dan Kebudayaan, pp. 28, 1979/1980.

[4] R.M. Soedarsono, Masa Gemilang dan Memudar Wayang Wong Gaya Yogyakarta. Yogyakarta: Tarawang, pp. 3, 2000.
[5] E.W. Rahayu, W. Nugraha, A.M.H. Kusmayati, "Rokat Pandhaba Sebagai Pertunjukan Budaya Masyarakat Madura di Kabupaten Sumenep," Geter: Jurnal Seni Drama, Tari, dan Musik, vol. 1, no. $1, \quad$ pp. $9-22, \quad 2018$. DOI: http://dx.doi.org/10.26740/geter.v1n1.p9-22

[6] J. Sumardjo, Perkembangan Teater Modern dan Sastra Drama Indonesia. Bandung: STSI Press, 2004.

[7] A.M.H. Kusmayati, Rokat Bangkalan: Penjelajahan Makna dan Struktur. Bandung: MSPI, 1998.

[8] I.S. Ibrahim and B.A. Akhmad, Komunikasi dan Komodifikasi (Mengkaji Media dan Budaya Dalam Dinamika Globalisasi). Jakarta: Yayasan Pustaka Obor Indonesia, 2014. Available: https://repodosen.ulm.ac.id//handle/123456789/17682

[9] M.J. Lee, Kebudayaan, Konsumsi, \& Komoditas. Bantul: Kreasi Wacana, 2015.

[10] I.S. Ibrahim and B.A. Akhmad, Komunikasi dan Komodifikasi (Mengkaji Media dan Budaya Dalam Dinamika Globalisasi). Jakarta: Yayasan Pustaka Obor Indonesia, 2014.

[11] J.P. Baudrillard. Masyarakat Konsumsi. Yogyakarta: Kreasi Wacana, 2013.

[12] C. Barker, "Cultural Studies: Teori dan Praktik," in Cultural Studies: Theory and Practice, Tim Kunci Cultural Studies Center (Ed.). Yogyakarta: PT. Bentang Pustaka, 2005.

[13] A.A.M. Djelantik, Estetika Sebuah Pengantar. Bandung: Masyarakat Seni Pertunjukan Indonesia bekerjasama dengan Arti Line, 1991.

[14] B. Suharto and J. Smith, Komposisi Tari Sebuah Petunjuk Praktis Bagi Guru. Yogyakarta: Ekalasti, 1985.

[15] S. Murgiyanto, Koreografi: Pengetahuan Dasar Komposisi Tari. Jakarta: Depdikbud, 1983.

[16] S. Soedarsono, Tari-Tarian Indonesia 1. Jakarta: Direktorat Jenderal Kebudayaan, 2004. Available: http://pustaka.kebudayaan.kemdikbud.go.id/index.p $\mathrm{hp} ? \mathrm{p}=$ show_detail\&id=3536\&keywords=tarian + tari an+indonesia

[17] S. Murgiyanto, Kritik Tari, Bekal dan Kemampuan Dasar. Jakarta: Masyarakat Seni Pertunjukan Indonesia (MSPI), 2002.

[18] H. Bouvier, Lèbur: Seni Musik dan Pertunjukan Dalam Masyarakat Madura. Jakarta: Yayasan Asosiasi Tradisi Lisan dan Yayasan Obor Indonesia, 2002. 